\title{
The Death and Posthumous Life of Tom Sawyer: A Case Study of Apparent After-Death Communication
}

\author{
Kenneth Ring, Ph.D. \\ Kentfield, $C A$
}

Many readers of this journal will be familiar with the name of Tom Sawyer - not Mark Twain's fictional character, but an equally memorable and well known near-death experiencer who died of pulmonary fibrosis in April, 2007. Or did he? That, as someone even more famous once wrote, "is the question."

To start at the beginning, I initially encountered Tom a few months after publishing my first book on NDEs, Life at Death (Ring, 1980). $\mathrm{He}$ had come across the book and, having had a powerful and lifechanging NDE a couple of years earlier, was eager to talk to me about it.

After a brief telephone conversation, he promised to send me a copy of a cassette he had recorded of his experience, which he had made not long after the event. Once I had had a chance to listen to it, I invited Tom to visit me where I was then living - at what we had come to call "The Near-Death Hotel," my home near the University of Connecticut (see chapter one of my book, Heading Toward Omega, 1984, for a description), and where quite a few near-death experiencers came to spend time and share their experiences with me and my family in an informal setting.

Tom turned out to be a powerfully-built blonde young man with an engagingly boyish, "aw, shucks" manner. Indeed, his name really seemed to suit him because he actually looked like the kind of "allAmerican boy" of the sort that Frank Capra might have cast in one of his heartwarming films of the 1940 s. Tom had a ready smile, a distinctly "corny" sense of humor, as seemed to befit his working class background (he was for years a heavy-equipment operator for the city of Rochester, New York), and a mouth that wouldn't quit. As I recall, it 
took him nearly two hours that first day to give an account of his NDE, which surprisingly was marked by many long pauses when he would tear up and become so emotional that he couldn't continue. As 'I'om repeatedly told us apologetically, in narrating his experience he was actually reliving it and experiencing again all the overwhelming feelings that had originally marked his encounter with death.

During that first year of our acquaintance, I got to know Tom and his family quite well, as we continued to exchange visits, and not long afterward, I wrote about him extensively in my next book, Heading Toward Omega (Ring, 1984, see especially pp. 56-59 and 114-120). I don't need to recapitulate Tom's NDE here, but to lay the groundwork for what is to follow, I must excerpt just a few words concerning what he said at the end of the original tape that he had sent me when he spoke about his understanding of death in the light (no pun intended) of his NDE:

As a result of that [experience], I have very little apprehension about dying my natural death...because if death is anything, anything at all like what I experienced, it's gotta be the most wonderful thing to look forward to, absolutely the most wonderful thing. (Ring, 1984, p. 59.)

After those initial encounters with Tom, we had only occasional personal contact (Tom wasn't a writer - he was a talker! - and this was also before the days of e-mail), but we would still see each other on special occasions, such as when we made a video together, or at conferences where I was speaking when, suddenly, I would run into Tom, not even having had any prior knowledge that he was there (this happened a couple of times when I was lecturing in Europe, example).

And over the years, Tom went on to develop a very sizeable followin' as a result of the talks and seminars he was asked to give - some of them, according to what I have been told, going on for days at a time with Tom scarcely ever even pausing long enough to take a bathroom break. During these years, his talks reached many ears and affected so many people so profoundly that Tom became something of a guru to those who were drawn to his teachings. Eventually one of these persons, Sidney Saylor Farr, wrote two books about Tom's life and thought, What Tom Sawyer Learned from Dying (Farr, 1993) and Tom Sawyer and the Spiritual Whirlwind (Farr, 2000).

During this time, while I continued to hear about Tom's work, travels, and adventures, my main connection to him was still through 
that cassette tape he had originally given to me, which I often played for my NDE classes and workshops, because it was just about the most emotionally compelling account of an NDE, and especially the encounter with the Light, I had in my possession. As a result, Tom's words, and even the sound of his voice, became indelibly etched in my mind.

Then, early in 2007, I heard from Tom again - this time, uncharacteristically, by e-mail. He wrote to tell me that he was dying.

\section{The Death of Tom Sawyer}

His first e-mail was vintage Tom, and I will reproduce some of it here just to give readers the sense of the man and the way he communicated:

Hello, long almost lost, good buddy. Not to waste time, I will say, I am absolutely content, at peace, and ready to make that transition. I am using 15-20 Liters of O2. A huge amount. I have good people (hospice, doctors, etc) helping me.

I miss your company. If you would like, I would be receptive to communicate further. I would prefer anything of "length" via e-mail. It's easier to breathe (tee hee). And, would you be interested in receiving selected pictures and/or paperwork that I am sorting through and (mostly) trashing. It would be the type of stuff that you would like to see and then either keep or throw out. Let me know, my friend.

- Tom Sawyer

Naturally, I responded immediately and kept in touch with Tom, and others who were close to him, during the ensuing two months prior to his death. Needless to say, these heartfelt exchanges meant a lot to me, and I hope my own notes to him helped to cheer him a bit, though, truth to tell, he seemed to be uncommonly cheerful and at peace up to the very end. Just a few days before Tom died, he sent a package to me containing a beautiful and personally meaningful gift, but he also enclosed with it a letter in which he told me how he had come to express the love to so many people that he had felt when in the Light. One day in 1981, Tom wrote, at an NDE conference at Yale University, the woman with whom I lived at the Near-Death Hotel my "near-wife, as I jokingly called her - who was a great hugger, gave Tom a hug, and according to him, it was a hug that changed his life. Tom then went on with a long page about his life as a world-class 
hugger, and, writing about himself in the third person, concluded his letter with these words:

Tom has hugged thousands of individuals. He has hugged adults, children, and friends and, yes - even enemies. Tom has shared some rare hugs with dying people, Nobel Laureates, garbage men, murderers, and even the Dalai Lama [with whom Tom had a private audience in Dharmasala].

This, Tom said, was one of the best ways he could personally convey to others the essence of what he had experienced while in the Light.

And that was Tom's farewell note to me. A few days later, he was dead.

Afterward, I learned from one of his close friends that his leavetaking was perfectly in character: He was joking with the nurses until almost the very end. And when he told them that he was to die on a certain day (which coincided, perhaps not by chance, with his wife's birthday), they didn't believe him. Nevertheless, when it was his time, he went, presumably with great joy, back to the Light.

A few days after his death, I heard that one of the persons who had been a devoted student of Tom's had decided to set up a Web site in order to provide an opportunity for those who knew and loved Tom to share their memories of and feelings about him. Naturally, I decided to write a little tribute of my own, and in the course of doing so learned that the woman, Kim Wise, who had created the site lived only a few miles from me. As a result, not long afterward, Kim and I had a chance to meet and share with each other our own memories and experiences with Tom. And in short order, we had become very good friends, too, linked as we were through our respective relationships with our mutual friend.

And that was the end of it - or so it seemed. Although Kim and I would still occasionally talk about Tom, our lives soon were coursing through their usual channels. Besides, as I had learned from Kim and some of Tom's other friends, he had specifically advised them that after his death they should not expect to hear anything more from him - he clearly had other plans and would not be in touch.

Therefore, it was with a distinct sense of surprise that more than half a year after Tom's death, I received an e-mail from Kim that began as follows:

I've heard interesting information on our friend, Tom Sawyer. As much as he said that he wouldn't be around, indeed he is! I'm putting 
into one document the several emails that relate and will attach them here. We can discuss the next time we speak.

The most provocative of these documents turned out to a long account that was furnished by the paramedic who just happened to accompany Tom to the hospital the day before his death on April, 28, 2007, and who had not known Tom or anything about him before this time. She was to learn a great deal about him after his death, however, but not by the usual means. Her story, which is the real heart of this article but which circles back to the original question I posed in its opening paragraph, follows.

\section{The Apparent After-Death Life of Tom Sawyer}

Lynda Cummings Dickerson is a 37-year-old married woman, the mother of five children. Born in Montreal, she has lived for some years in Rochester, New York, the same city where Tom Sawyer had resided.

For most of the past 16 years, Lynda has worked as a full time paramedic, though in recent years, because of her busy family life, she has had to cut back and has been able to work only part time. It was in that connection that she had her only encounter with Tom shortly before his death. But after it, she was to have many experiences of Tom that convinced her that he was still very much alive. Never having had anything like this happen to her previously, and being of a skeptical turn of mind, she was psychologically "rocked" by these experiences. She was not only incredulous, but she felt that she "was going crazy." Fortunately, she soon kept a record of what was happening to her and some months later wrote up an 8,000-word account of her apparent encounters with Tom in his postmortem state. After learning about Sidney Farr's books concerning Tom, she sent this document to Farr, who forwarded it to Kim Wise, who then sent it on to me.

Much of the rest of this article will draw from Lynda's account, so it is really her story I will be telling here. However, before beginning this narration, I should say that since reading her document, I have had extensive e-mail and some telephone contact with Lynda, and though I have not yet had a chance to meet her, I personally have no doubt that her account of her experiences can be trusted to be an accurate rendition of what took place in her life following the death of Tom Sawyer. 
Lynda began her story with a kind of preface in which she made clear that the events that were about to unfold in her life were definitely not the sort of thing that her pragmatic, down-to-earth approach to the world had prepared her for:

I never had an "experience" like those I have read about, such as "my son's favorite animal was a fox, and the day after we buried him, a fox ran up to my back door, and I knew it was a message from him." A nice story, though my skeptic mind can't help but wonder, in their grief did they not wish to see something?

She then went to provide a little background on who she is and the way she has been used to working as a paramedic:

First, I'm not crazy. I'm a normal mom, with five kids and a bunch of pets. I am constantly busy, have no time for anything for myself and live the same life as every other suburban busy mom. I am currently a part-time paramedic. I had been full-time up until two years ago, working urban and suburban EMS (ambulance) for 16 years. I usually love it. I have unfortunately seen a lot of death, young deaths, older deaths, horrible deaths, and peaceful deaths. I have been involved in a lot of people's "worst day" of their life. As a protection mechanism, we usually develop a hard outside crusty, skeptical shell. These deaths do not become a part of my life. I can usually forget them by the end of the day; if not that day, the next. By the time I punch out I regularly cannot answe1 the question "what kind of calls did you have today." I can't remember name, address, or family. If I get behind in my documentation, I get all the people confused. I still show compassion, but it is done as soon as the patient is off my gurney. Again, a protection mechanism.

After this introduction, Lynda is ready to tell what happened to her the day she met Tom, an encounter that was clearly uncharacteristic for her in several respects:

The weirdness started on Thursday 4/26/07. I called to work Saturday; the supervisor talked me into Friday also. (This NEVER happens, I'm always too busy for spontaneous stuff and usually can only work on my terms...but hey, I took this shift.)

Friday 4/27/07. We were sent to the busiest post (we park the rig and wait for calls around the county). I sat for nearly four hours with no calls. My partner commented several times, this never happens! Our first call four hours into our shift was Tom Sawyer. My partner explained she hates hospice transports; they can be emotionally difficult for her. She was outta luck, it was her turn, and her sob story didn't sway me. I mentioned I have never had a problem with a hospice job. I guess I just believe the patient is moving to a better 
place. I still feel for the family, but at the end of shift, usually at the end of the call - I'm fine.

I didn't feel any special connection with Tom Sawyer in Tom's home. Once we got into the rig, my partner started her thing, she recalls Tom from when she was a waitress at Country Village and she would serve him and the Greece town guys. She and Tom joked a bit, we all joked a bit. I started to take over. As I did, I said, "I'll take this one." My partner was baffled, "Are you sure?" (In the paramedic world I am the senior partner, and hospices are BLS jobs [basic life support jobs] that would make it my partner's call; taking such a call is very generous). I couldn't explain, but I simply had a heavy feeling that I was supposed to. Sounds very corny, even as I write it now. There was no good reason; I had not made any particular "patient bond" or anything. It was just I felt I was supposed to. We started en route, and Tom wanted to talk. He was short of breath, over-exerting himself, but he wanted to talk, so we did. He explained he was a carpenter, had "built" a lot of Rochester. But he was on oxygen, and it was a bit difficult.

Two things about me, I was raised in Montreal; my favorite city in the U.S. is New Orleans. Having been there six times between August, 2001, and two months before Katrina, I have not been back since. When I arrive in New Orleans, I am immediately engulfed in a peaceful feeling of home. I love that city. So we talked about Louisiana [where Tom used to fish with his sons, Todd and Tim]. I asked something about whether he had visited since Katrina, he said yes, in fact, his wife Elaine was there now, celebrating her birthday [and attending] the jazz festival. He said that he and Elaine had talked about what [would] happen if he died on her birthday. He didn't want to ruin her birthday; he didn't want that to be the day he died. He said he wanted her to go to the jazz festival. She deserved a break; Elaine loves it there.

He explained he thought he had had a stroke that morning. He'd lost use of his left side; things weren't working right. He's had "this" for 10 years, six years of it fighting hard, but not as hard as today. I asked him what "this" was, what disease has brought him here. He explained, pulmonary fibrosis. He explained it was caused by a contaminant in his lungs, like the ash (at the landfill) for 20 years. Or the mercury bath he took in the building off Child and Ames streets in his early twenties, to see if he would be buoyant. He said, probably not a very good decision, but all his own decisions. Free will. He is not a victim. He has led a great life with a great family, and it was all a result of his own free will decisions. He also mentioned how his friend Richard helped him after Elaine left. He was almost choked up that a friend, a buddy, would do that for a friend, he was so appreciative. He explained he had been to Tibet, and how he was to get a private meeting with the Dalai Lama, though he is not a follower. He felt it was an incredible experience. 
He talked about Todd and Tim, Elaine, and how proud he was of them. He [had] traveled the world. He fit in so many things, he was proud of that.

We got closer to the hospital; he said he wanted to do this alone. Absolutely no visitors.

He was just so tired. So, so tired of fighting, he wanted to wait to die, but didn't think he could. He hoped Elaine would understand why; he seemed to think she would.

When we got to the room, several nurses walked in with us, like four. That's unusual. Now hospice nurses are what I believe to be angels on earth, sweet, soft, delicate, and attentive to no end. But you usually only get one, and maybe a tech, not four! I even looked at their name tags to see what the big turnout was for. Was this a VIP I didn't know was a VIP? As I left, I touched him, a long touch on his shoulder, leg, then foot. I wanted to stay. I walked out of the room, and a nurse followed me and asked if I was OK (of course I'm OK. Why wouldn't I be OK?) And as we walked to the elevator I remarked to my partner, "That was a hard one, my hardest one." My partner felt it too. At the end of shift we often all get together to shoot the breeze - people compare "good calls" and funny stories. I did mention Tom (not by name); I said simply "I had one of those hospice calls that touches you, that really stays with you." In the next few days, I told several people about Tom. Again, weird for me as I usually can turn off after a shift.

In the days following, Lynda found that she was still thinking about Tom quite a bit:

I checked the newspaper a few times that week to see if he was in the obits. When I didn't see him, I remember thinking, maybe Elaine got back in time, maybe he rallied, maybe this isn't his time. Then: very specifically thinking, why on earth has this man, this regular old patient, taken up so much space in my head? What would be the point if he's just about to die, or did die? I wish I knew more of him. I thought of visiting him, but recalled he said NO VISITORS.

On Saturday I saw the obits, and found Tom's. It was a surprise (?) shock (?) it took my breath away for a moment... Again, there are weeks where I know a few people in the obits. I don't react this way.

This is supposed to be the end of the story. This is the end of the factual, common sense, explainable part of the story.

In fact, it was to be only the beginning of an entirely new story - the beginning of signs, synchronicities, and intimations of Tom Sawyer by which, not to make a joke, Lynda was to become increasingly "spooked," so much so, as she was frank to admit, she soon comes to feel as if she is in danger of losing her mind altogether. But what Lynda doesn't know at this point - but what anyone who knew Tom well could attest - is that Tom is starting to manifest to her with all of 
his old earthly personality quirks and mannerisms intact. He is, then, still recognizably Tom to anyone who knew him. It was as if - though Lynda doesn't put it this way - she is now "channeling Tom Sawyer." And he wants something from her.

I found out later he died Saturday 4/28 - on Elaine's birthday. He was cremated. A "Celebration of Life" would be on Memorial Day weekend. Later, Richard told me he stayed there [at the hospice] for a long time. Richard said that after he left, Tom joked with the nurses. The nurses came in and out, checking on him at 15-minute intervals, and he chose one of the few moments alone, after Richard had left and the nurse was gone, to pass. It was so sudden. When the nurse returned, she thought he was just joking, but he had really passed.

Back to my everyday life. I thought of Tom a lot during the week. Saturday 5/5/07, I moved a lilac air freshener into the bathroom, suddenly at 12:30 a.m. (I don't know why). Sunday was uneventful. Monday when I woke up, I sent everyone off to school and meditated for a few minutes since I was just learning in a class on this. I had to stop, as all I could think of was Tom. When I walked into the bathroom there was a whiff of lilacs, and it made me think of Tom (I don't know why lilacs). What I can only describe as strong, strong feelings, a pressure, and a physical sensation almost. I know it's clichéd, but it felt like someone was there. Like Tom was in the room, slightly behind me over my right shoulder. And my thoughts had answers and feelings I had no business feeling. How do I know this? Why do I feel this so strongly? But it wasn't my worry; I could feel in my belly 'worry' and 'love' for Elaine and their kids. I could distance myself: That was not mine. I do not have any feelings for Elaine or her kids, but in my stomach, in my heart, the love and proudness was initiated, and echoed for them. "Tom, is this how you feel about your family?" It was guttural. It was affirmative. I went through a series of questions that were either positive, negative, and sometimes shown to me. I feel he wanted to get a message to them.

I thought, that is it, I have finally blown a fuse, and I think someone's trying to talk to me. I seriously, seriously was concerned for my mental health. But there was no reason; everything in my life is good, really GREAT. We just moved to a new home, under a bit of stress, but nothing like the crushing stress of three to six years ago (after my divorce), and I survived that. I was concerned. I thought I was going crazy. Somehow my ego had gotten out of control and perhaps I was projecting feelings into this situation.

Then, in my mind's eye, I "saw," "was shown," a picture of a man at 9/11 in a crane, working at the WTC site. The story I had read a while ago was about a hard old construction worker who all of a sudden felt a presence in his cab. He felt the "presence" wanted assistance; he tried to ignore it but it stayed for days. The construction worker did not believe in ghosts, spirits, and this stuff, but it was so strong, so persistent, he too thought he was losing his mind. He talked to his 
wife or friend and they decided to at least talk to someone spiritual, who mentioned it could be a spirit who attached himself to him for a reason. I don't know exactly how it ended, but the crane operator got help from a medium, and long story short, he was on national TV telling everyone how he knew now exactly what happened; the spirit needed his help. He did help it with the help of the medium. The spirit vanished, and all was well. The crane operator knew the spirit was friendly.

So I keep seeing the WTC with huge cranes flashing in my mind. Over and over again, I can picture Tom laughing, joking, smiling, but in good health, unlike how I saw him in his last hours. In fact the picture in my mind was so clear of him healthy, that's how I picture him. I can feel his sense of humor, as if he was following me through my day and silly comments, or double entendres he found funny (but I didn't necessarily). He would laugh. I could "feel" his teasing, "rascally" self at times. Certainly nothing that I really saw the day I saw Tom. I started to develop a sense of his and mine. "I didn't really like that joke, but it's very funny to Tom." I could feel his personality. Very strong, very used to getting his way, very precise, organized and planned. After a couple of days I used the word "dogged." I felt he was with me and at my heels and he was not going to let me get away with just leaving this be. (I would think, "Lynda, you are being crazy, stop thinking of this, period.") At some points I became so frazzled, from what felt like a sixth child pursuing me. I started talking directly to him at this point. [This was on May, 7, 2007.]

"OK, what if you are really here - why?" After I got the kids to school, I talked aloud. "I feel you are with me, Tom, is this right?" A feeling of calm, peace, and "positive energy." I haven't done anything like this, so I am winging it. I had two rocks I picked up. I clearly said, "OK, if this is real and you are here, give me a sign." What sign? I had a rock in each hand. I said Left hand is YES, Right Hand Rock is NO (I guess I expected nothing to really happen). I was heading to put them in a cup and maybe roll them out or something like a dice, I really didn't even have a plan, when the left hand rock dropped out, flew out of my hand, to my left. By itself. My very first thought was, clumsy, how did I drop it like that? The very next thought was: THAT WAS YOUR SIGN! I stopped in my tracks. I could feel the discussion. Me: "That's not really a sign, I just dropped it." Tom: A joke here of some sort, a feeling of laughter from Tom, like: "are you kidding me? That WAS your sign, and a pretty great sign at that." These words were not literal, it was a feeling. I continued to deny it, but I could feel him, me: "I need a better sign! Clearer." And a feeling of "Oh, c'mon give me a break. That WAS YOUR sign, and you need to acknowledge that sign before we continue." Again NOT literal wording. Now this is part of the funny part, negotiation of sorts. Tom: "That was distinctly your sign, exactly as you wanted it. Exactly as you said it."

I was spinning. I had to take a break, I researched "After Death Communications," and it kind of explained I might not be crazy; 
others had similar experiences. So I really had to let it sink in. I was chewing this over. I got in the car and my country station had been changed to an 80's station (I always listen to country), the song lyrics were "I am watching you."

A nursing magazine I subscribe to: The front page is, "What to do if your patient experiences a near-death experience." I get in the car again, and the song is "holes in the floors of heaven," or something like that.

My son has a special blanket; it had been missing for at least several days. So we searched at night and the next morning. Nick was upset because he thought it was lost. Everyone went to school. As I was putting away laundry, just before the kids got home, [I found] the blanket was placed precisely, and obviously, at the foot of his bed. If Nick had found it, he wouldn't have been upset as he went to school the bigger kids leave for school earlier, so they weren't there for the search or its replacement. I checked with my husband and he had no idea where it had been, and he didn't find it. So I asked Tom, I didn't get a definite "positive' or "negative;" I got a smirk. I do think it was he.

So I talked to him some more. I asked for more signs, and I would be dense to ignore all that. Through questions, I wrote four pages of "things," specifics for Elaine. Basically: He wanted Elaine to know how much he loved her, they had talked about it, but on the other side "love" is so enormous, it can't be described, and even though they talked about it he wanted to re-iterate how immense and totally encompassing his love for her and the children was. Their love for him was so much larger and encompassing than he understood and that love helped him be in the wonderful place he is. But he really needed them to know; I had to try to tell them how much he loved them, even though he had tried to tell them. He was so, so very proud of his kids. I could feel it in my stomach, and it echoed my proudness for my kids, almost to the point of bringing me to tears.

Second: He had tried to plan everything and control everything about his death. He wanted Elaine out of town, so he could die without having to have a tough side, and he thought it would 'hurt' her less. He thought it would be easier for him as well. What he learned was the love was so great, he now knows he couldn't control it. That, because of the great enormous love, the grief was inevitable.

At this point, Tom clearly wants Lynda to become his messenger. He needs her to go to Elaine and tell her what Tom so desperately wants his wife to know.

I knew nothing of his other activities, except he had been a carpenter and worked for the town of Greece. I [knew] that as a paramedic I could be putting my career in jeopardy if I contacted his family, that this was just plain, completely crazy and I had to stop. 
Tom was so, so persistent, he won. I'd give what I thought he wanted a try, [but first] I had to stop at Barnes and Noble and pick up a book, Allison Dubois's We Are Their Heaven [Dubois, 2006]. It explained part of how he felt. The title anyway. I had the book and had already given it away, without completing it, because she talked a lot about dead kids and I couldn't get through it. BUT TOM wanted me to stop by his house, talk to his wife and drop off this book and my notes. I drove there (to their home) the whole time talking to God about me being crazy, and to Tom, if this is really what you want. As I headed over there I knew it was the right thing. As I pulled into the driveway, I said if this were supposed to be, she'd be home. Elaine (who I had not met yet) was not there. I got back in my car, absolutely sure I should drive directly to the psych wing, as I was obviously way insane. I had NOT left the book. As I discussed this with myself, what I had come to recognize as "Tom's presence" showed up (just the feeling, I never "saw" him).

He was what I felt as exasperated, impatient, almost stomping his feet for me to go back, almost like a little kid. It took a little while, but finally I turned around, and figured maybe she was out to lunch and we missed each other. (He wasn't frustrated or mad at me or Elaine; it was as if he was exasperated because he was trying to work these two ends together and it was not coordinating right.) So I go back. I kind of bounced between believing Tom was there communicating, and believing there was no such thing as Tom, and I was having a breakdown. Well, if I am having a breakdown, I might as well complete whatever "adventure" I thought I was having. So I tuned into Tom, returned to the driveway, wrote a note that loosely said "I helped care for Tom in his last 24 hours, if you would like to talk with me, please call me at -..-- and if this is in any way uncomfortable, please never mind this and accept my condolence, and God Bless."

She called me within two hours and I was floored. I was just so sure she'd think I was nuts. She said she wanted to meet, but things were so crazy she would call me back "in a few days" and we'd schedule something. Absolutely fine by me, I had done my job. But I could literally feel Tom's exasperation; He wanted us to meet sooner, even now! This is a perfect example of my being able to differentiate between MY FEELINGS (next week was fine with me, I am in no hurry) and HIS FEELINGS of: "I'll settle for that since it's as good as it gets, but I am not thrilled." I said to him, at least I went back, left the book, and didn't chicken out! I am doing the best I can...I felt him pacified.

His presence was sparse and infrequent the next $48 \mathrm{hrs}$. I felt MUCH better because I could feel him NOT there, which made me feel NOT crazy.

Friday, I was home alone (a rarity in a house of seven people), and I decided to take a slow shower around 5 p.m., a luxury, since normally things are crazy, and I shower in the morning. I am halfway through my shower, literally conditioner in my hair and all soaped up, when I 
feel Tom. I feel urgency to get out of the shower, get out now! You are going to miss it! At that point, I am exhausted and I say out loud, "Tom, listen mister, I have been driving myself crazy for days trying to get this right, and right now, I have no kids, no husband, and I have a minute to myself, unless the house is on fire, please just let me take a shower!!" I felt a laugh, like an "all right, I'll give you a break." The urgency decreased, but it still felt like the doorbell was ringing, or someone was waiting for me, so I did conclude my shower instead of lollygagging. "You happy, Tom?" I was joking and talking aloud, I did not actually feel urgency at this point. I got my bathrobe on, hair in a towel, and I walked directly to my cell phone, [and] YOU GUESSED IT: Elaine had just called at 5:04 p.m. and left me a message. I was dizzy I was so affected. I returned her call. We made a specific time and date to meet. I did not go into detail on the phone; she knows I was part of the ambulance crew that took him to the hospital that day. Check with Tom; again he would like it faster but at least the appointment's made. He eases up; I don't feel him much for the next couple of days. In fact, I feel happiness that things are "set."

So I met with her. I started off gently. Explaining exactly what happened in real concrete terms. What we talked about, etc. Then, thinking for sure she would think I am crazy at least, or hurt her more at worst, I decided to plunge, and tell her something weird had been happening. She responded as calmly and reassuringly as if I had said, "I bought new tires." She said, "Go ahead, and tell me what's going on, weird things always happened to Tom." I explained and showed her the pages I wrote. She had a few questions. She answered a few questions. We spoke for an hour and a half, and the only reason we ended was because my kids were with a babysitter. She showed me a picture of Tom healthy. I felt that I recognized him as well in the picture as in my mind's eye. I didn't say anything about that. She explained they had traveled many places. They'd had a good life together. She started off by saying, "I'm not mad at him anymore, I forgive him now (at the time I wasn't sure exactly what for, but through our conversations later she explained). She forgave him for dying without her, for dying on her birthday, and it's what he wanted, so she was no longer mad. (She hadn't wanted to go since he appeared so sick, but he wanted her to go.) She explained quickly, and showed me a picture of Tibet; she proudly mentioned the Dalai Lama. She didn't go into detail. She showed me a picture of herself 15 years ago. She explained that Tom had had a near-death experience, and that landed them on the Oprah show. No other explanation. I did not ask further questions. As I departed, I felt like I had said what Tom wanted without causing distress. We decided we would try to meet again, no specific date. She invited me to the celebration of life for Tom, but I declined.

Her mission complete, Lynda is now ready to take a break, thinking Tom is finally done with her. But she can't help thinking about him 
and what has happened to her because of him. And from her conversation with Elaine, she now knows about Tom's near-death experience and the fact that he's been on Oprah. Intrigued, she decides to find out more about this new man in her life:

I took a break. I thought I was done. I tried to turn it all off. Mostly it was off. I was in disbelief, but I felt like something incredible had happened. I don't know what, but it was something. The crane operator flashed often in my head, and I figured I was just supposed to tell Elaine what I did. Mental break for a couple of days. I had told Elaine she could have a copy of my notes, and a few days later I copied the notes and was sitting at the computer. Really, I felt him NOT there during these "break days." I remembered Elaine mentioning Oprah and his near-death experience, so as I sealed the envelope, I typed into Google "Oprah, Tom Sawyer near death." In the top 10, up pops the first page: "What Tom Sawyer Learned From Dying" by Sidney Farr. It was an excerpt from his/your book, which at this point I had no idea existed. The wind was knocked out of me. So far I knew he worked for the town of Greece, he traveled a lot, he had pulmonary fibrosis, and he had touched me like no one else. I was dizzy and nauseous. It was just SO MUCH TO SORT. It's not like it was a book on plumbing or a mystery fiction novel!! It's a book on his last days and beyond, and how he believed in telepathic communication and he's in MY HEAD. I called up Elaine. She was so cool. I left an almost frantic message. I said, I just came across the book and I was shocked. There was so much to this story, I feel like there's an entire chapter of explanation I have missed. If she felt comfortable, could she call me back? She called back almost immediately. She calmly said, why, yes, there was, and that's why this wasn't weird to her. I wasn't mad of course, but here I am sure I'm insane for a week or two and I am not (at least no more than a bunch of other people). We kept the conversation short. She said I wasn't crazy, and she'd be happy to fill me in on the blanks a bit later as she was very busy - no problem. That in itself was reassuring. I hung up. I sat, still spinning.

But now that Lynda knows more about Tom and has been at least momentarily reassured that despite her persisting doubts to the contrary, she is not "nuts," she wants to go deeper into this mystery and see where else it might lead. And it is just here that she receives in a most unexpected way the culminating confirmation that what she has been experiencing is no mere delusion, but the real thing:

So I'm trying to figure out what to do next. Some Internet research led me to "spiritualists" and what they believe, and a Rochester "Spiritualist" church. I figured if you can consult a priest or rabbi about spiritual stuff, maybe the boss at this church could help me. I woke up early Sunday, thought of attending, then seriously considered rolling over and going back to bed when Tom expressed 
somehow that I needed to go. I attended. It was nice. The format was talk, meditate, and heal, then "messages." I wasn't exactly sure what this was, but I was guessing, and I was close. Now I'm better figuring out when Tom was there or when Tom wasn't. And he was there, I could feel him over my right shoulder. I wonder can people here see him? Feel him? Or is this all one big mass hysteria, and I'm nuts?

So to the message part: I'm in the back row, arms and feet crossed, probably emanating skepticism. I was overwhelmed. Three "student" mediums go up to the pulpit and give brief messages. None of which I found to be generic; they were very specific. I do not have a German grandma happy that I'm learning to cook German dishes, to carry on traditions, but clearly the woman who received the message felt it was on the money as she nodded and cried. So one, two, medium students deliver messages that appear to make sense to those receiving them. There are 60 to 70 people in the church. I start talking to Tom, "Listen buddy, I've been hopping through quite a bit of hoops, disrupting my life, trying to figure what you need, please, please show up, just to let me know I am not crazy, that I am on the right track." A third student medium started [but] never looked in my direction. I feel Tom there and I feel his answer. Laughing at my impatience, or the way I was talking to him mostly, and I feel him "say": "I'm not going through the students, I'm waiting for the Big Kahuna, the REVEREND herself, then you will believe!" (At this point I didn't realize the format, and wasn't aware that she, Robin Higgins, the Reverend of this Church, would even deliver messages, as the time appeared to have run out. We were approaching more an hour, well over the church services I was used to, but it flew by.) Well, doesn't Rev. Higgins start talking. She says before she concludes, she has a couple of messages: This is it! This is it! She looks to the opposite side of the room and says, "Sir, may I give you a message?" I was so disappointed; I didn't even hear what she said. TOM: "Hang on, hang on, she's not done." Rev. Higgins looks right at me, in the back row and says, "For you, in the white, I promise if you uncross your arms and legs and let me feel your heart, I have a message for you!" She closes her eyes and starts talking: "You have a male energy standing behind you, he's free of pain now, and he thanks you for your help, you helped him in his transition. His hand is on your shoulder and he shows me that you helped him walk, helped him stand, when he was too weak to do it himself." AT THIS POINT SHE BENDS down, gestures exactly the gestures I did to help lift him, to help him stand as we had to carry him on a special chair to the gurney because we could not get the gurney in the house because his son's boat kind of blocked the door. Her hand placement was exactly the placement mine had been as I was on his right side and that would be different than if I had been on his left. She repeated the gestures and movement a second time. "He says thank you, and he's there for you. But wait, he says to tell you he's not there all the time. He says to make sure I tell you that because he says YOU don't want him there 
all the time." She places her hands over her eyes and laughs, "He's joking, laughing, it's important you know he's not 'watching you all the time.' You were worried about that, but he's there when you need him." And she ended "and I leave this with God's blessing." She gave one more message to someone, but I heard not a word.

OK, I believe. I was done. I was shocked. I was spinning like I was in a tornado.

As I left, I spoke to the assistant reverend. I explained, something's going on, and could she help me? Because I don't know what to do with this, or what to do next, and I'm a step away from going crazy. We made an appointment for the next day.

Again, I'll abbreviate. Robin was calm, reassuring. I explained my story at 900 m.p.h. I refer to Tom as a presence. I also referred to him as Tom, but not TOM SAWYER. When I got to the part about finding his book on Google, I pulled out the article/excerpt I had printed out and said "Tom Sawyer..." and handed it to her. She interrupts: "Did you say Tom Sawyer?" Literally, her jaw was open. She stared at me, then the paper, she looked at her assistant who was also there and said: “Tom Sawyer?" Assistant says: “Tom Sawyer?" I said: "Yes, his name is Tom Sawyer, not the Huckleberry Finn guy. The Huckleberry Finn guy isn't talking to me. Tom was a patient of mine, I took him to the hospital, that's his real name!" She repeats, "You are talking about Tom Sawyer. Tom Sawyer is talking to you." Calmly, not in a question format, in a statement format. For the first time in all this I was scared. "What's the matter? What's the matter?" Thoughts ran through my head: "Do they think I am crazy? Have I gone too far?" I wonder how the psych wing looks, and how am I going to explain this to my husband. She resets to her original calm, soothing disposition. Makes direct eye contact, puts her hand on my knee: "We know Tom Sawyer."

Robin says she doesn't personally know Tom, [but] they are both part of IANDS, and she had done a talk, and Tom and she had talked on the phone. And just a few weeks ago Tom wanted to attend her lecture, but his illness was too advanced, so she recorded it for him and sent him a copy. But that's not the only thing.

One of her students, Lois, has been coming in; she feels Spirit and is so moved she cries. She's been feeling him, but wasn't aware he had passed away. Lois drew his blood on a weekly basis, knew him, and was currently reading his/your book. She was thinking he may need help and was going to stop at his house. They were just talking about him yesterday. NOT DONE yet. Two other friends of Tom were going to be attending her all-day mediumship class on Saturday in two weeks. They were mutual friends from IANDS. (I still had no idea what IANDS was but I'd figure that out.) She says, "Tom sent you here because he has opened a door for you, and here's where I can get help to manage this. She said I should attend the mediumship class as it will explain everything, catch me up to speed of sorts, since this is all new to me. She said it was NOT accidental, this was all supposed 
to happen. Robin said, Tom is sending me people for this class. Good people who have medium skills. Tom has a very, very strong soul. She called it the beginning of "Spiritual Enfoldment," and often it felt like insanity, but she filled me in on a whole bunch of stuff that made me feel better. If I was going crazy, there was a whole pile of people who were there waiting for me, who understood me. Just before we ended, I blurted out: "Tom wants to be in your book." I had no knowledge she was at chapter eight, writing her own book.

I attended the class, learned a whole bunch, Tom didn't come. In fact since my meeting with Robin, I had felt him hardly at all. Now I started to get nervous - what if that was it, what if he DOESN'T come back? I want him to come back! Robin said he may have done what he had to do and continued on his way now that everything was accomplished. Sometimes that happens, some people will hear from one person, and it never happens again, but she said that's not what she sees for me - there's more to come. We just have to manage it so I don't overload and quit. She said, this is how it started for her, about 15 years ago, but there was no one to tell her it was Spirit and not insanity.

As Robin had inferred, even though Lynda had seemingly come once again to the end of her journey with Tom and was now about to enter into a new stage of her spiritual development, he was not quite done with her:

Memorial Day weekend we were camping (yuck) with friends. I had NOT planned on going to the Celebration of Life; I felt it would be intruding.

Well, Tom had different plans. In fact, my husband now needed to work Sunday, and we'd be back around 12 or 1 p.m. on Sunday instead of Monday. It had been a few days, maybe even a week or two, and I hadn't felt Tom at all. Now he was there, he wanted me to go. OK, I'll go. I'll stop by; it was right near my house. We pulled into town at 1 p.m. The celebration started at 1 p.m., so I hightailed it over there. Rather uncomfortable as I knew no one. Then I saw Lois and Robin. Lois wanted to attend and Robin was there for moral support. The two people in her class next week were there also. I saw Richard again (Richard had been there the day I picked up Tom in the ambulance). Apparently, Richard, Tom's best buddy, was also all into spiritual stuff. Robin had already talked with Richard and mentioned that Lois and I had had visits, as he was open to this. He was very excited to talk with me, as he had not felt Tom yet. We would talk later, a different day.

Long story short again, I start getting these feelings again while I was there, overwhelming pride in my stomach, so strong. How Tom felt about his kids - Todd knows, but you need to tell Tim, just as I emphasized it for Elaine. Tom wanted me to tell Tim. I thought it wasn't respectful, that it was intruding. I left. 
I was driving down the street when all I could feel was Tom, that's WHY he wanted me there, [for] Richard and Tim. I had to go back and talk to Tim, as I wouldn't have another opportunity. OK then. I turned around, went back, someone pointed him out, but I actually knew who he was the second I saw him. I blurted out what I felt, what I felt Tom wanted me to say. I did not do a good job. Tim must think I am crazy. Tom wasn't thrilled with either my delivery or Tim's reception, as if Tim didn't really hear what I was trying to say but all the right words came out. I did the best I could. End of that.

Long story short, Richard and I met for lunch. I have tons to say to these willing ears. Most importantly, Tom underestimated people's love for him and had tried to control the situation, the grief. As if he and Richard had talked and being on the same page, knowing Tom was moving to a better place. Richard felt he shouldn't be sad. But Richard was sad; he was trying not to be, but he couldn't help it. Tom was saying, "Hey bud, never mind what we discussed, it's OK to grieve and be sad sometime." Tom could really feel Richard's deep love for him. And thank you, but don't let it bring you down for too long. I explained everything to Richard, who only said he believed it WAS a message for him, Elaine and Tim. It made complete sense, even the way I said it, and he believed Tom is guiding me in a specific direction.

Richard then filled me in on lots of stuff that verified things I felt, explained why Tim would get THAT message but not Todd. He filled in so many blanks, shared lots of stories, because so far I only knew little bits. He also gave me a copy of the book. Which was amazing.

Lynda's last words are now specifically directed to the author of that book, Sidney Farr, who had already devoted so much of her time to Tom and who had, more than anyone else, brought Tom's remarkable life and thought to a larger public:

Your words, explaining how you felt it was time to write that book, sounds as if you may understand some of this. Since then, I've been reading, learning about things I never imagined. Tom pops in and out. I don't feel him often anymore, but the mediumship class I took has led to several other "messages," which apparently have been accurate. Also, I wait until they come to me, so I don't dive bomb them like poor Tim. I've figured out how to sort and turn things on or off.

If any of this is believable to you, I felt there was some stuff from Tom to you as well. If you haven't "felt" it yet yourself, which I'm sure you have. As I read your words, I felt you were one of the people who he wanted me to give this info to - Elaine, Richard, Tim, and you. I'm sorry it took so long, but I can't help but feel there was a reason for the delay, either on my side or yours. I'm doing better at accepting "everything happens for a reason" and "patience." When I started writing this 'story,' it was 5/14/07; it sounds so naïve as I reread the 
beginning. It was originally aimed at Elaine, and I was describing the beginning before I realized Elaine was open. But it describes how clueless I was. Then I decided to tell the story, and it's time to share it with you. Tom wanted me to write it all out and send it to you now.

\section{The Aftermath: The Widening Circle}

After Lynda had made contact with Sidney Farr, it became clear to her that she (Lynda) had more work to do for Tom. In effect, Tom communicated to her that he wanted her to be the instrumentality through which the most important members of his group of loyal followers could be assured of Tom's continued existence, of his great love for them, and of the fact that he wanted them to mobilize themselves to continue to spread his message to a greater audience.

During this time, Lynda would find certain images popping into her head when she felt Tom's presence. One, for example, involved "The Blues Brothers: 'Let's get the Band back together.' I see Dan Ackroyd and John Belushi in black suits and sunglasses." Lynda still has no idea that there is thought to be in the spiritual realm a benevolent group of beings known as The Blue Brotherhood, something of which Tom was aware. And not only that but this brotherhood had actually been consciously invoked by one of Tom's closest friends who feels himself to be spiritually aligned with this group with the aim of assisting Tom to make the transition from life here to whatever may be said to follow physical life. In one of the e-mails sent by this person to Tom shortly before his death, he actually wrote "You are my dear friend and teammate on the Blue-Brothers team." Was it coincidence that Lynda suddenly started to think of the Blues Brothers in connection with Tom? We can only speculate.

In any case, by this time I was in touch with Lynda myself by e-mail. And by then she had become very clear concerning just what it was that Tom wanted her to convey to his most devoted students:

What's this all about? It's time to get the friends moving again. It's time to continue...spreading his message of love...There are enough people [that] if they continue his/their work, it will make a difference. THAT I hear Loud and Clear. Loud and clear is, the friends have had enough of a break, it's time to get crackin'. Each has something to contribute in their own way. Also, he would like his message of love, and how his message has touched and changed people's lives, to be compiled. I am assisting in compilation, I'm helping connect people and make that a smooth transition. There are several camps that 
need to work together to make what he wants successful. I might be able to help.

In another e-mail to Sidney, Lynda elaborated on Tom's message of the continuity of love that she was picking up from him:

Your love and need to care for your loved ones doesn't just turn off when you change worlds. You still LOVE your people, you don't just disappear (From My Fair Lady, "By God, I think she's got it!" echoes in my brain.). You don't just stop because you are dead, your soul continues to love. Tom not contacting, loving and caring for his loved ones in life would be unnatural. He wouldn't ever just stop caring for loved ones. He'd never just stop. So his not contacting, touching, loving, watching out for his loved ones NOW would also be unnatural. Some can feel it, some cannot, but he is there.

It was during this period also that Lynda began hearing from and meeting a number of Tom's closest associates, some of whom had been very struck by the authenticity of the communications she appeared to be transmitting from Tom. It also became apparent during this time both to Lynda and to me that a number of other individuals who had been close to Tom had been feeling his presence and in some cases were already receiving messages similar to those that Lynda had been conveying, particularly about Tom's apparent wish that his work be continued on earth. Lynda was now communicating regularly by email to Tom's group and in a note addressed to "Friends of Tom," she summed up for them what she felt she had been "commissioned" by him to communicate to them:

What it means to me is...about getting everyone up and going. Up and going, involves continuing your personal contribution towards spreading Tom's message of love on a daily basis, and somehow getting coordinated as a group, if you should choose this mission, to make a big contribution of positive energy that will have an impact on the world. You guys know what he means!

If you've always wanted to write a book, teach a class, write an article, paint a picture that you think would contribute to spreading the message, start it now! He wants to tell his stories!! He wants people to know he was a regular guy who had a big impact, and you can have a big impact and show others how THEY can have a big impact. Starting by telling his stories where the door opens for one to be told...So don't hesitate. Even the smallest of stories can have an impact.

Naturally, I myself had thought about whether I might contribute to this undertaking in some way, particularly by writing something about Tom. I had already begun thinking about this after first reading 
Lynda's original document to Sidney Farr, but it wasn't long before Lynda herself in some of her subsequent messages both to me and to others was suggesting that this might be Tom's wish, too. For example, in one of her first notes to me, Lynda remarked that despite her concern about her document being passed on to others, "it's good that it got to Kim, but he was AIMING for you." Then, over the next few days, sometimes in distinctly uncanny ways, I began to hear similar messages from several other people, one of whom had no prior knowledge of any of the developments described in this article, all to the effect that Tom wanted me to become involved in "telling his story." Subsequent e-mails from Lynda only reinforced that impression.

This leads to you...Ken will know what to do next - what Tom's getting at. Though these other people were to help deliver the message to Ken, these other friends will be needed for the rest of the "project".

O.K., a simpler way to say this, Lynda would have no reason to just call up and contact Ken. This way, Tom is rallying his troops AND you are back involved... When I say he was aiming for you - he's back, and it's time for you all to get working. "Uh," he "says" he makes me "feel" you "know darn well" what he means. I do not have the frame of reference to understand all that's involved (yet).

When I specifically ask - "Tom, do you have a message for Ken?" I get the warm smile feeling with a slightly sarcastic "Well, isn't that enough?"

Then, one night in the midst of all this, I had a dream, which I recounted to Lynda the following morning:

Curiously enough, Lynda (or perhaps not!), last night, fairly early in my sleep cycle, sometime after midnight, I awoke from a very strange experience and remember thinking, "that's weird." I've lost some of the details now, but as I remember I dreamed that after having got out of my shower at home, I discovered that several things, such as stuff on my desk and computer table had obviously been moved. But since I was alone, I could not figure out - in the dream, I mean - how this had happened. I then found myself fiddling with an old cassette player, trying to dislodge a tape of the kind I had used to record Tom - although I wasn't thinking then either of Tom or his tape. But suddenly I heard Tom's voice - distinctly - speaking to me, and as I recall, with some sense of humor. I don't recall what he was saying, but when I heard his voice, I immediately woke up with a start, which is what prompted me to say "that's weird."

To the best of my knowledge, this is the first time I've ever dreamed of Tom or heard his voice in my dream. Assuming it was a dream. I don't necessarily give this experience any paranormal significance 
since I was talking and thinking a lot about Tom yesterday, so on the principle of Occam's razor, a purely psychological explanation would be most probable and parsimonious. But since you had said in your note last night that "Tom was sending me something," perhaps that was it. Who knows?

All of these oddities and synchronicities as well as Lynda's communications had by now persuaded me that there was certainly something to all of this and that someone should write it up, perhaps even as a book. Having been retired for some years, I wasn't eager to take on a book, however, and thought that Sidney Farr would be a far better choice, anyway, given her history with Tom. But when I suggested this, she declined for reasons of health. The ball seemed to be back in my court, and while I temporized, I remained in touch with both Lynda and Kim Wise, pondering my options. Ultimately, ensuing developments with Tom's group and some of Lynda's communications suggested that the most feasible writing project for me, at least for now, would involve preparing an article for this Journal. When I proposed this to Lynda, she was very supportive: "A journal article would be just right... We'll assume those who need to see it will, how about that?" And then later that same day in a follow-up note, she added this, "I'm very happy about an article, and look forward to working with you. I also think Tom is happy about it."

In her most recent communication to me, on February 10, 2008, Lynda summed up where she was now with all this and what she sensed from Tom about the status of what she had helped put into motion:

Tom has not been so strong as to interrupt my everyday life since December. I, however, will check in at times. Sometimes he is NOT there. Sometimes he is there. When I start working on a project about or for him, often eventually I feel him clearly.

Like right now - he didn't start it, but as I get writing, I feel him strongly. He's sending me warm and happy, smiling feelings. I ask, how does he feel about the stuff down here? Is it going in the right direction? I feel a very positive, almost excited vibe. There are several "stokes in the fire." Ken is one of them and it's going beautifully. This article will lead to something, which will lead to something. It's all going as it is supposed to.

Meanwhile, Lynda has come to feel that she has pretty much fulfilled Tom's charge. She has stimulated his group to become more active again in order to continue in their own way to further Tom's contributions to the spiritual welfare of humanity, she has reassured 
his loved ones and precious friends of how much Tom continues to love and care for them, and of course that he continues, at least for now, to exist as the same Tom Sawyer they knew and loved while he was on this earth. And although Lynda didn't and couldn't consciously recognize this, her subjectively compelling encounters with Tom following his physical death serve only to buttress Tom's own claim about what death is like, as he recounted it following his near-death experience in 1978 when he said in the words I have already quoted:

As a result of that [experience], I have very little apprehension about dying my natural death...because if death is anything, anything at all like what I experienced, it's gotta be the most wonderful thing to look forward to, absolutely the most wonderful thing. (Ring, 1984, p. 59.)

\section{References}

DuBois, A. (2006). We are their heaven. New York: Fireside.

Farr, S. S. (1993). What Tom Sawyer learned from dying. Norfolk, VA: Hampton Roads. Farr, S. S. (2000). Tom Sawyer \& the spiritual whirlwind. Berea, KY: Ochamois.

Ring, K. (1980). Life at death. New York: Coward, McCann and Geoghegan.

Ring, K. (1984). Heading toward omega. New York: William Morrow. 